\title{
Association between the M235T polymorphism of the AGT gene and cytokines in patients with hypertension
}

\author{
JING-LIN CHENG ${ }^{1}$, AI-LING WANG ${ }^{2}$ and $\mathrm{JUN}_{\text {WAN }}^{2}$ \\ ${ }^{1}$ Department of Emergency, Second Affiliated Hospital of Anhui Medical University, Hefei 230601; \\ ${ }^{2}$ Department of Cardiology, First Affiliated Hospital of Anhui Medical University, Hefei 230032, P.R. China
}

Received October 18, 2011; Accepted December 12, 2011

DOI: 10.3892/etm.2011.433

\begin{abstract}
The aim of the present study was to explore the association between the M235T polymorphism of the angiotensinogen (AGT) gene and cytokines in patients with essential hypertension (EH). A total of 300 patients with $\mathrm{EH}$ and an agematched control group of 150 individuals without $\mathrm{EH}$, secondary hypertension, myocardial infarction and diabetes were enrolled in this study. Polymerase chain reaction combined with restriction fragment length polymorphism (PCR-RFLP) was used to detect variation in the target genotype, and enzyme-linked immunosorbant assay (ELISA) was used to detect the cytokine [interleukin (IL)-1, IL-6 and tumor necrosis factor- $\alpha$ (TNF- $\alpha$ )] concentrations. The AGT gene 235T allele and 235TT genotype frequencies in hypertensive patients were slightly higher than those in the controls. Furthermore, in the hypertensive subjects with the AGT gene 235T allele, the concentrations of IL-1 and TNF- $\alpha$ were significant higher than those in the controls. The results from our study suggest that the higher AGT gene TT genotype and $235 \mathrm{~T}$ allele frequencies may be risk factors for hypertension. High frequencies of the AGT gene 235T allele and high cytokine concentrations (IL-1 and TNF- $\alpha$ ) may promote the transcription and expression of AGT, particularly in hypertensive patients with the 235TT genotype.
\end{abstract}

\section{Introduction}

Hypertension has been recognized as a significant risk factor for the development of cardiovascular diseases, including coronary heart disease (CHD), myocardial infarction (MI) and stroke, all of which are principal causes of cardiovascular morbidity and mortality in humans. Essential hypertension $(\mathrm{EH})$ is a complex, polygenic disease in which numerous genes control the blood pressure level. Several candidate genes, all

Correspondence to: Professor Ai-Ling Wang, Department of Cardiology, First Affiliated Hospital of Anhui Medical University, 218 Jixi Road, Hefei 230032, P.R. China

E-mail:wal2010@yahoo.cn

Key words: angiotensinogen gene, cytokine, essential hypertension selected from the renin-angiotensin system-related genes, have been examined. One of the candidate genes is the gene encoding angiotensinogen (AGT), the precursor of the vasoactive peptide, angiotensin II. The angiotensin I-converting enzyme (ACE) gene has also been associated with EH in the majority of the population. In recent years, the correlation between the molecular variant of the AGT gene, M235T, and $\mathrm{EH}$ has started to receive attention (1-6). AGT in the circulation is mainly synthesized in the liver. The plasma AGT level mainly reflects this synthesis. It has been discovered that the expression of the AGT gene in the liver is regulated by certain cytokines. It has been reported that these cytokines [interleukin (IL)-1, IL-6 and tumor necrosis factor- $\alpha$ (TNF- $\alpha$ )] are likely to be the main activation factors in AGT gene expression. They activate the expression of the AGT gene, elevate the concentrations of AGT and ultimately accelerate the development of hypertension. In addition, IL-1 and TNF- $\alpha$ also induce proliferation of the smooth muscle blood vessel cells and arteriosclerosis. Studies on the association between the M235T polymorphism of the AGT gene and cytokines in hypertensive Chinese patients have been rarely reported. The aim of this study was to analyze the M235T polymorphism of the AGT gene and cytokine levels in Chinese patients with EH and compare them to healthy controls. Such a complex study is the first to be carried out in China.

\section{Materials and methods}

Hypertensive patients. The study group consisted of 300 patients with EH. All patients were hospitalized in the Department of Cardiology, First Affiliated Hospital of Anhui Medical University, China and included 120 males (40\%) with a mean age of $55.11 \pm 8.41$ years and 180 females $(60 \%)$ with a mean age of $58 \pm 10.19$ years. Risk factors for $\mathrm{EH}$ were obtained by standard questionnaires, physical examinations and blood tests. The patients were asked about their medical history, family history of hypertension, smoking habit and alcohol consumption. Blood pressure was measured by standard methods. All patients had an onset of hypertension prior to the age of 50 years. We considered patients to have EH if they had a systolic blood pressure (SBP) above $140 \mathrm{mmHg}$ and/ or a diastolic blood pressure (DBP) above $90 \mathrm{mmHg}$ at the time of examination, and no clinical evidence of secondary hypertension. 
Table I. Main characteristics of the hypertensive group and the healthy controls.

\begin{tabular}{lcc}
\hline Characteristics of cases $(\mathrm{n})$ & $\begin{array}{c}\text { Hypertensive group }(\mathrm{n}=300) \\
\mathrm{n}(\%)\end{array}$ & $\begin{array}{c}\text { Healthy controls }(\mathrm{n}=150) \\
\mathrm{n}(\%)\end{array}$ \\
\hline Female & $180(60.0)$ & $95(63.3)$ \\
Mean age, years & $58.0 \pm 10.2$ & $53.2 \pm 12.3$ \\
Alcohol consumption & $16(8.9)$ & $15(15.8)$ \\
Cigarette smoking (at least 10 cigarettes daily) & $15(8.3)$ & $7(4.7)$ \\
Familial history of hypertension & $68(37.8)$ & $0(0)$ \\
Male & $120(40.0)$ & $55(36.7)$ \\
Mean age; years & $55.1 \pm 8.4$ & $51.6 \pm 20.9$ \\
Alcohol consumption & $25(20.8)$ & $28(50.9)$ \\
Cigarette smoking (at least 10 cigarettes daily) & $50(41.7)$ & $15(27.3)$ \\
Familial history of hypertension & $94(78.3)$ & $0(0)$
\end{tabular}

Healthy controls. The healthy control group consisted of 150 age-matched individuals. The group of normotensive individuals included 55 males $(36.67 \%)$ with a mean age of $51.55 \pm 20.89$ years and 95 females $(63.33 \%)$ with a mean age of $53.16 \pm 12.26$ years. None of the individuals from the control group had symptoms of EH. They each had an SBP lower than $140 \mathrm{mmHg}$ and a DBP lower than $90 \mathrm{mmHg}$. None of the control group subjects had a positive familial history of EH or MI. None of these individuals had secondary hypertension or diabetes. All the individuals in the control group had never been treated with anti-hypertensive medication. All EH patients and healthy controls provided informed consent, and responded to a questionnaire that provided information concerning risk factors of hypertension, including alcohol consumption, cigarette smoking and familial history of hypertension. The study and DNA analysis were approved by the ethics board of our university. The main characteristics of the two groups are presented in Table I.

Blood pressure measurement. Blood pressure was measured using a mercury-gravity manometer. Measurements were recorded using the left arm with subjects in the seated position following $10 \mathrm{~min}$ of resting. This procedure was repeated three times, and the systolic and diastolic blood pressures were defined as the means of the three independent measurements.

Materials. The primers for polymerase chain reaction (PCR) were purchased from the Institute of Biochemistry and Cell Biology, Shanghai, China. Taq enzymes were provided by HuaMei Co., Shanghai. The cytokine determination reagent boxes of IL-1, IL- 6 and TNF- $\alpha$ were provided by Genezyme Co., Cambridge, MA, USA.

DNA isolation and PCR-restriction fragment length polymorphism (RFLP). In order to identify the M235T polymorphism of the AGT gene, $3 \mathrm{ml}$ of venous blood was drawn into tubes containing $0.3 \mathrm{ml}$ of $2 \%$ EDTA, and was centrifuged for $10 \mathrm{~min}$ at 5,000 rpm. The blood plasma was separated and preserved at $-20^{\circ} \mathrm{C}$, and the surplus blood cells were mixed with $20 \mathrm{ml}$ of distilled water. The red blood cells were hemolyzed after $15 \mathrm{~min}$ and were centrifuged for $10 \mathrm{~min}$ at 5,000 rpm. The precipitated white blood cells, without the supernatants, were preserved at $-20^{\circ} \mathrm{C}$. The white blood cell DNA was then digested with Proteinase $\mathrm{K}$, extracted with phenol and chloroform, and then preserved at $-20^{\circ} \mathrm{C}$. The analysis took 3 months.

PCR-RFLP was used to examine the M235T polymorphism of the AGT gene. The primers used to amplify the DNA fragment (98 bp) were as follows: primer 1 (627-646 nt), 5'-AGA ACT GGA TGT TGC TGC TG-3'; and primer 2 (724-705 nt), 5'-TGC TGT CCA CAC TGG CTC GC-3'. PCR was carried out in a $50 \mu \mathrm{l}$ volume with 35 cycles of amplification $\left(92^{\circ} \mathrm{C}\right.$ for $44 \mathrm{sec}, 55^{\circ} \mathrm{C}$ for $40 \mathrm{sec}$ and $72^{\circ} \mathrm{C}$ for $90 \mathrm{sec}$ ) with a final extension at $72^{\circ} \mathrm{C}$ for $10 \mathrm{~min}$. The M235T polymorphism of the AGT gene was detected by the digestion of the PCR products with a $B s t \mathrm{UI}$ restriction enzyme, and the digestion was performed in a $10 \mu \mathrm{l}$ reaction mixture. The digested products were separated by electrophoresis on a $2 \%$ agarose gel or $7 \%$ PAGE with silver staining. The positive M235T polymorphism of the AGT gene was confirmed by DNA sequencing (data not shown).

Enzyme-linked immunosorbent assay (ELISA). This was used to detect the concentrations of the cytokines (IL-1, IL-6 and TNF- $\alpha$ ). The determination reagent boxes of IL-1, IL-6 and TNF- $\alpha$ were as follows: i) gene recombination IL-1, purity $>98 \%, 2 \times 10^{7} \mathrm{u} / \mathrm{mg}$; ii) gene recombination IL-6, purity $>96 \%$, $2 \times 10^{7} \mathrm{u} / \mathrm{mg}$; iii) gene recombination $\mathrm{TNF}-\alpha$, purity $>96 \%$, $1.5 \times 10^{7} \mathrm{u} / \mathrm{mg}$. The determination using microELISA was performed according to the manufacturer's instructions.

Statistical analysis. All the data were expressed as the means \pm SD. Statistical analyses of the differences between the two groups were performed using the homogeneity test for variance and the unpaired data t-test. The intergroup difference was judged to be significant at $\mathrm{P}<0.05$, and was considered to be greatly significant at $\mathrm{P}<0.01$.

\section{Results}

Hardy-Weinberg equilibrium. The distribution of the AGT gene 235T/M genotype in the hypertensive and healthy control group 
Table II. M235T AGT genotypes in the hypertensive group and the healthy controls.

\begin{tabular}{lcc}
\hline & $\begin{array}{c}\text { Hypertensive } \\
\text { group }\end{array}$ & $\begin{array}{c}\text { Healthy } \\
\text { controls }\end{array}$ \\
\hline No. of cases & 300 & 150 \\
TT genotype, $\mathrm{n}(\%)$ & $165(55)$ & $69(46)$ \\
MT genotype, $\mathrm{n}(\%)$ & $108(36)$ & $66(44)$ \\
MM genotype, n (\%) & $27(9)$ & $15(10)$ \\
\hline
\end{tabular}

TT genotype, patients homozygous for M235T AGT variant with 2 copies of the T235 allele; TM genotype, patients heterozygous for M235T AGT variant with 1 copy of the T235 allele and with 1 copy of the M235 allele; MM genotype, patients negative for the M235T AGT variant with 2 copies of the M235 allele.

Table III. T and $\mathrm{M}$ allele frequencies for the hypertensive group and the healthy controls and the cytokine concentrations (IL-1, IL-6 and TNF- $\alpha$ ) (means \pm SD).

\begin{tabular}{lrrrrr}
\hline & \multicolumn{2}{c}{$\begin{array}{c}\text { Hypertensive group } \\
(300)\end{array}$} & & \multicolumn{2}{c}{$\begin{array}{c}\text { Healthy controls } \\
(150)\end{array}$} \\
\cline { 2 - 3 } \cline { 6 - 6 } Group & $\mathrm{T}(73 \%)$ & $\mathrm{M}(27 \%)$ & & $\mathrm{T}(6 \%)$ & $\mathrm{M}(32 \%)$ \\
\hline $\mathrm{IL}-1(\mathrm{ng} / \mathrm{ml})$ & $13.4 \pm 3.8^{\mathrm{a}}$ & $9.4 \pm 2.8^{\mathrm{b}}$ & & $10.8 \pm 3.3$ & $8.7 \pm 3.3$ \\
$\mathrm{IL}-6(\mathrm{ng} / \mathrm{ml})$ & $3.9 \pm 1.3^{\mathrm{b}}$ & $5.8 \pm 2.7^{\mathrm{b}}$ & & $5.6 \pm 2.4$ & $4.4 \pm 3.2$ \\
$\mathrm{TNF}-\alpha(\mathrm{ng} / \mathrm{ml})$ & $11.4 \pm 2.6^{\mathrm{a}}$ & $10.4 \pm 3.5^{\mathrm{b}}$ & & $7.7 \pm 2.2$ & $9.3 \pm 2.3$ \\
\hline
\end{tabular}

${ }^{\mathrm{a}} \mathrm{P}<0.01,{ }^{\mathrm{b}} \mathrm{P}>0.05$, vs. the same allele frequency of the controls.

subjects, recruited from city of Hefei in China, was analyzed using the Hardy-Weinberg equilibrium $\left(\chi^{2}=0.032, \mathrm{P}>0.05\right)$.

AGT gene 235TT, TM and MM genotypes. Three genotypes (TT, TM and MM) were detected in the 235 codon of the AGT gene. In the hypertensive group, the percentages for the AGT gene TT genotype, MT genotype and MM genotype were 55,36 and $9 \%$, respectively. The ratio of the T/M allele frequency was $0.73 / 0.27$. In the control group, the percentages for the AGT gene TT genotype, MT genotype and MM genotype were 46,44 and $10 \%$, respectively. The AGT ratio of $\mathrm{T} / \mathrm{M}$ allele frequency was $0.68 / 0.32$. In addition, the AGT gene 235TT genotype and $\mathrm{T}$ allele frequencies in the hypertensive group were significantly higher than those in the control group $(\mathrm{P}<0.05)$ (Table II).

The correlation between $T$ and $M$ allele frequency and the cytokine concentrations. The correlation between the $\mathrm{T}$ and $\mathrm{M}$ allele frequency and the cytokine concentrations (IL-1, IL- 6 and TNF- $\alpha$ ) in the two groups was compared. There was a significant difference in the average concentrations of cytokines (IL-1 and TNF- $\alpha$ ) in the patients with the AGT gene 235T allele between the hypertensive group and the healthy control group $(\mathrm{P}<0.01)$. However, there was no significant
Table IV. Cytokine (IL-1, IL-6 and TNF- $\alpha$ ) concentrations in the hypertensive group and the healthy controls (means $\pm \mathrm{SD}$ ).

\begin{tabular}{lcc}
\hline & $\begin{array}{c}\text { Hypertensive } \\
\text { group }\end{array}$ & $\begin{array}{c}\text { Healthy } \\
\text { controls }\end{array}$ \\
\hline No. of cases & 300 & 150 \\
IL-1 $(\mathrm{ng} / \mathrm{ml})$ & $12.9 \pm 3.6^{\mathrm{a}}$ & $9.5 \pm 3.0$ \\
$\mathrm{IL}-6(\mathrm{ng} / \mathrm{ml})$ & $4.5 \pm 2.5^{\mathrm{b}}$ & $5.0 \pm 2.9$ \\
$\mathrm{TNF}-\alpha(\mathrm{ng} / \mathrm{ml})$ & $11.2 \pm 3.0^{\mathrm{a}}$ & 7.91 .9 \\
\hline
\end{tabular}

${ }^{\mathrm{a}} \mathrm{P}<0.01,{ }^{\mathrm{b}} \mathrm{P}>0.05$

difference in the average cytokine concentrations of (IL-1, IL-6 and TNF- $\alpha$ ) in the patients with the AGT gene $235 \mathrm{M}$ allele between the two groups $(\mathrm{P}>0.05)$ (Table III).

The blood concentrations of $I L-1, I L-6$ and TNF- $\alpha$. There were significant differences in the blood concentrations of IL-1 and TNF- $\alpha$ between the patients in the hypertensive group and those in the healthy control group $(\mathrm{P}<0.01)$, but there was no difference in IL-6 ( $>0.05)$ (Table IV).

\section{Discussion}

This study explored the association between the M235T polymorphism of the AGT gene and cytokine concentrations using age-matched individuals with different backgrounds. In this way, our results were more concise compared to those from studies using stochastic control groups.

In the last few years, the M235T polymorphism of the AGT gene has been investigated for an association with $\mathrm{EH}$, based on conventional measurements of blood pressure. However, the results have been inconsistent. There have been a number of studies that have confirmed a positive association between M235T variants and hypertension (6-8), but certain studies have confirmed a lack of significant effect of the AGT M235T polymorphism $(9,10)$. This means that different populations may have a different AGT M235T polymorphism.

Previously, an extensive study on the potential role of the AGT gene in EH was performed by Jeunemaitre et al in two large series of 379 sibling pairs. They found genetic linkage between EH and AGT in the affected siblings and an elevated M235T allele frequency, compared to healthy controls. In the second year of this study, results from the same group confirmed an association between the M235T variants and EH (11).

Another study conducted in a Japanese population of 352 individuals, with a mean age of 52.5 years, reported no association between the M235T variant of the AGT gene and EH (12). Rotimi et al studied the association between EH and the M235T variant in the African-American population. They revealed that the frequency of the 235T allele was $83 \%$ in hypertensive patients and $82 \%$ in control subjects. These results offered no evidence of a linkage between the 235T allele and EH in the African-American population (13).

The variety in these results could be due to differences in ethnicity. The results of our study suggest an association 
between the M235T polymorphism in the gene encoding AGT in Chinese patients with EH. Three genotypes (TT, TM and MM) were separated from the 235 codon in the AGT gene using PCR-RFCP. Among the 300 Chinese patients with $\mathrm{EH}, 36 \%$ were heterozygous (genotype TM) and 55 and $9 \%$ were homozygous (genotype TT and MM); while among the healthy Chinese controls, $44 \%$ were heterozygous (genotype TM) and 46 and 10\% were homozygous (genotype TT and $\mathrm{MM}$ ) (Table II). In the hypertensive group, the ratio of the $\mathrm{T} / \mathrm{M}$ allele frequency was $0.73 / 0.27$. In the control group, the ratio of the T/M allele frequency was $0.68 / 0.32$. The AGT gene 235TT genotype and $\mathrm{T}$ allele frequencies in the hypertensive group were significantly higher than those in the control group. This was a preliminary study and more cases are required for further study. Further investigation is required to clarify the potential involvement of the M235T polymorphism.

We also discovered that the blood concentrations of the cytokines (IL-1 and TNF- $\alpha$ ) in the hypertensive group were markedly higher than those in the control group $(\mathrm{P}<0.01)$, while there was no significant difference in IL-6 concentration between the two groups $(\mathrm{P}>0.05)$. In addition, there were significant differences in the average concentrations of IL-1 and TNF- $\alpha$ in the AGT gene 235T allele $(\mathrm{P}<0.01)$, but not in the AGT gene $235 \mathrm{M}$ allele $(\mathrm{P}>0.05)$. Our study suggests that hypertension occurs and becomes aggravated easily in individuals who are carriers of the AGT gene T allele when the concentrations of cytokines (IL-1 and TNF- $\alpha$ ) in the carriers are elevated. High levels of IL-1 and TNF- $\alpha$ may promote inflammation, higher expression of AGT and $\mathrm{Ca}^{2+}$ movement into the vascular smooth muscle cells (VSMC) in EH patients. $\mathrm{EH}$ is a type of inflammation-related disease.

In conclusion, we consider that the AGT gene moleculer variant, M235T, may be a significant risk factor and hereditary marker for EH. The higher frequency of the AGT gene TT genotype and the AGT gene 235T allele may promote the development of hypertension. In EH patients with the AGT gene 235T allele, elevated concentrations of IL-1 and TNF- $\alpha$ may enhance the transcription and expression of the AGT gene and may cause the blood vessels to constrict.

\section{References}

1. Ji LD, Zhang LN, Shen P, et al: Association of angiotensinogen gene M235T and angiotensin-converting enzyme gene I/D polymorphisms with essential hypertension in Han Chinese population: a meta-analysis. J Hypertension 28: 419-428, 2010.

2. Markovic D, Tang X, Guruju M, et al: Association of angiotensinogen gene polymorphisms with essential hypertension in African-Americans and Caucasians. Hum Hered 60: 89-96, 2005.

3. Yuan J, Tang W, Chun Y, et al: Angiotensinogen T174M and M235T variants and hypertension in the Hani and Yi minority groups of China. Biochem Genet 47: 344-350, 2009.

4. Tiago AD, Samani NJ, Candy GP, Brooksbank R, et al: Angiotensinogen gene promoter region variant modifies body size-ambulatory blood pressure relations in hypertension. Circulation 106: 1483-1487, 2002.

5. Wu SJ, Chiang FT, Chen WJ, et al: Three single-nucleotide polymorphisms of the angiotensinogen gene and susceptibility to hypertension: single locus genotype vs. haplotype analysis. Physiol Genomics 17: 79-86, 2004.

6. Fang YJ, Deng HB, Thomas GN, et al: Linkage of angiotensinogen gene polymorphisms with hypertension in a sibling study of Hong Kong Chinese. J Hypertens 28: 1203-1209, 2010.

7. Lizanecz E, Pásztor ET, Mohácsi A, et al: Mistyping of angiotensiogen M235T alleles. Hypertens Res 29: 197-201, 2006.

8. Caulfield M, Lavender P, Farrall M, et al: Linkage of the angiotensinogen gene to essential hypertension. N Engl J Med 330: 1629-1633, 1994.

9. Glavnik N and Petrovic D: M235T polymorphism of the angiotensinogen gene and insertion/deletion polymorphism of the angiotensin- 1 converting enzyme gene in essential arterial hypertension in Caucasians. Folia Biol 53: 69-70, 2007.

10. Mettimano M, Lanni A, Migneco A, et al: Angiotensin-related genes involved in essential hypertension: allelic distribution in an Italian population sample. Ital Heart J 2: 589-593, 2001.

11. Jeunemaitre X, Charru A, Chatellier G, et al: M235T variant of the human angiotensinogen gene in unselected hypertensive patients. J Hypertens Suppl 11: S80-S81, 1993.

12. Ichihara S, Yokota M, Fujimura T, et al: Lack of association between variants of the angiotensinogen gene and the risk of coronary artery disease in middle-aged Japanese men. Am Heart J 134: 260-265, 1997.

13. Rotimi C, Morrison L, Cooper R, et al: Angiotensinogen gene in human hypertension. Lack of an association of the $235 \mathrm{~T}$ allele among African-Americans. Hypertension 24: 591-594, 1994.

14. Wang AL, Kong DH, Chen DX, et al: Mutation of V896M in cardiac myosin binding protein-c gene in two Chinese families with hypertrophic cardiomyopathy. Mol Med Report 3: 759-763, 2010. 